\title{
Control of Invasive Plants by the Phytotoxicity Effect of Sorghum bicolor [L.] Moench
}

\author{
Mateus L. O. Freitas ${ }^{1}$, Letycia L. Ricardo ${ }^{2}$, Patrícia da C. Zonetti ${ }^{2}$, Terciliana F. F. de Carvalho ${ }^{1}$, \\ Ricardo Andreola ${ }^{1}$, Aline M. O. Gonçalvez-Zuliani ${ }^{1}$, Anny R. Mannigel ${ }^{1}$, Jussara R. de Oliveira ${ }^{1}$, \\ Daniele F. Felipe ${ }^{1}$, Francielli Gasparotto ${ }^{1}$, Edison Schmidt-Filho ${ }^{1} \&$ Graciene de S. Bido ${ }^{1}$ \\ ${ }^{1}$ Cesumar University Center, Maringá, PR, Brazil \\ ${ }^{2}$ Federal University of Paraná, Palotina, PR, Brazil \\ Correspondence: Graciene de S. Bido, Cesumar University Center, Campus Maringá, Av. Guedner, 1610, Jardim \\ Aclimação, Maringá, Paraná, Brazil. Tel: 55-443-027-6360. E-mail: gsbido@hotmail.com
}

Received: April 20, 2019

Accepted: May 20, 2019 Online Published: July 15, 2019

doi:10.5539/jas.v11n10p313

URL: https://doi.org/10.5539/jas.v11n10p313

The research is financed by Cesumar University Center-UNICESUMAR.

\begin{abstract}
Owing to an increasing demand for food, a constant agricultural production flow must be maintained. Further, for doing so, the use of pesticides is necessary. An alternative that results in less damage to the ecosystem and people themselves may be identified by studies on the allelopathic effect of weeds. Therefore, this work aimed to evaluate the allelopathic action of hexane, dichloromethane, butanol, and ethyl acetate fractions of sorghum (Sorghum bicolor [L.] Moench) on the initial growth of morning glory (Ipomoea grandifolia [Dammer] O'Donell) and slim amaranth (Amaranthus hybridus L.), which was verified by the percentage of germination, speed of germination, seedling length, and fresh and dry biomass weight. The experiments were conducted in an incubation chamber at $25{ }^{\circ} \mathrm{C}$ for 7 and 14 days for morning glory and slim amaranth, respectively. The experimental design was completely randomized, with five replicates in Petri dishes. The data were evaluated by analysis of variance, and the averages between each treatment were compared using the Scott Knott test at a 5\% significance level. The results indicated that the dichloromethane and ethyl acetate fractions decreased the initial growth of morning glory and slim amaranth more, when compared with the effects of hexane and butanol.
\end{abstract}

Keywords: secondary metabolism, sorgoleone, weeds

\section{Introduction}

The global population is expanding daily. In Brazil, the population increases on average by about one person every $20 \mathrm{~s}$ (Instituto Brasileiro de Geografia e Estatística [IBGE], 2016). As a result, there is an increasing demand for food, which can be addressed by developing agriculture and livestock technologies.

Because of the need for increased production, it is necessary for most farmers to use pesticides, which can cause an ecological imbalance, especially when used inconsistently and in excess. Because of this, there are more risks to consumer health and the environment (Pinto, 2015).

The considerable increase in the use of applied agrochemicals could bring about a series of disturbances and modifications in the environment, either by the contamination of the living communities that compose the environment or by the accumulation of the agrochemicals in the biotic and abiotic segments of the ecosystem (Ribas \& Matsumura, 2009).

As an alternative against the incorrect and exacerbated use of agrochemicals, studies have been performed related to the allelopathic action of plants. These studies have searched for herbicidal or growth-regulating phytotoxins, since the synthetic versions of these products increase the proliferation of invasive, herbicide-resistant plants when used improperly. Phytotoxins generally belong to the class of secondary metabolites, which are less harmful to the environment when compared with agrochemicals (Magiero et al., 2009). 
As such, it is extremely important to carry out research in this field to determine the mechanisms of action, production, and decomposition of allelopathic compounds (Rosado et al., 2009). The term allelopathy originated from a study on the chemical interference that one plant species exerts on another. The word unifies the terms "allelon" and "pathos," which signify "mutual" and "injury," respectively. It is known that allelopathic compounds can exert positive effects on the receiver or may exert negative effects by impairing some species, populations, or even surrounding communities (Brass et al., 2009). Furthermore, allelopathy occurs when a plant, through its living or decomposing tissue, interferes with the growth of another plant (Zimdahl, 2007).

Although allelopathy has been verified in all organisms, it is more common and evident in plants. It is considered as one of the defense mechanisms against pathogens, pests, herbivores, and other plants. Even after death, allelochemical substances can remain in plant tissues and be released through volatization (for volatile products) or by leaching, through dew and rain (if soluble in the water), into the ground, thereby, when in sufficient concentration, they can influence the development of microorganisms and plants (Almeida, 1991). Therefore, the allelopathic effect can be pronounced both during the cropping cycle and in consecutive crops cultivated (Teixeira, Araújo, \& Carvalho, 2004).

Sorghum (Sorghum bicolor (L.) Moench) is considered a good alternative of cereals as a fall/winter crop, with the capability to tolerate water deficient conditions and a high capacity for water utilization and conversion to dry biomass. It should also be considered that sorghum straw has a high $\mathrm{C} / \mathrm{N}$ ratio and, consequently, a higher soil persistence (Landau \& Sans, 2008). Some studies have shown that the use of sorghum may allelopathically affect the development or germination of different plant species, such as wild poinsettia, morning glory, southern sandbur, and others (Carvalho, Teixeira, Neto, Moreira, \& Cunha, 2016; Gomes, Bevilaqua, Silva, \& Monquero, 2014; Oliveira, Peixoto, Poelking, \& Almeida et al., 2015).

Owing to its recognized allelopathic potential, sorghum has been used in intercropping systems to reduce the use of chemical herbicides. This is only possible because of the production of compounds with biological activity, such as sorgoleone. This compound is naturally present in expressive quantities in the trichomes of sorghum roots and inhibits the growth of invading plants through contact (I. L. V. L. Santos, Silva, S. L. Santos, \& Maia, 2012).

Morning glory (Ipomoea grandifolia [Dammer] O’Donell) is an annual angiosperm. Its best development occurs in tilled soil and under good humidity conditions. This plant has a round-branched stem with white hairs. The flowers emerge from the point where the leaves attach to the stem/branches. They are white in color at the base of the tube and pink at the top with a red center. The fruit is capsule-shaped and contains an average of four seeds (Gazziero et al., 2006). In addition, Ipomoea grandifolia (Dammer) O'Donell is a climber weed, characterized by the morphology of its stems and voluble branches that can get entangled with neighboring plants and grow over surfaces (Marques et al., 2005). Its presence in soybean fields can reduce crop productivity significantly, making harvesting, especially mechanical harvesting, difficult.

Slim amaranth (Amaranthus hybridus L.) is an annual, herbaceous, branched, erect, and pigmented angiosperm, which is about $40-100 \mathrm{~cm}$ high, native to tropical America, and a seed propagator. It is a weed plant of great importance and relatively high frequency in the south of the Brazilian country, mainly infesting cultivated soils of annual crops, orchards, coffee plantations, and vacant lots. It has a large reproductive capacity; a single plant can produce 117.000 seeds (Lorenzi, 2000).

Controlling invasive plants with a natural herbicide could eventually become a more economical, ecological, and sustainable alternative to chemical pesticides. Therefore, this study aimed to evaluate the allelopathic potential of sorghum, specifically on morning glory and slim amaranth weeds.

\section{Material and Methods}

The experiments were conducted from June 2016 to September 2018. Using a BOD (Biochemical Oxygen Demand) incubator (Logen), the germination and initial growth of the invading plants Ipomoea grandifolia (Dammer) O'Donell and Amaranthus hybridus L. were evaluated in the presence or absence of dichloromethane, hexane, butanol, and ethyl acetate fractions of Sorghum bicolor (L.) Moench.

\subsection{Obtaining Sorghum Fractions by Liquid-Liquid Extraction}

The dried and ground materials $(3.75 \mathrm{~kg})$ of the aerial parts of sorghum were extracted with cold methanol following maceration. After removal of the solvent under vacuum on a rotary evaporator at $33-35{ }^{\circ} \mathrm{C}$, the crude methanolic extract $(293.61 \mathrm{~g})$ was obtained.

The crude extract was dissolved in 3:1 methanol-water $(1.5 \mathrm{~L})$ and partitioned with $3 \times 300 \mathrm{~mL}$ of each of the organic solvents: hexane, dichloromethane, ethyl acetate, hydromethanol, and butanol. After removal of the 
solvents using a rotary evaporator, the following fractions remained: hexane (32.33 g), dichloromethane (4.48 $\mathrm{g})$, ethyl acetate $(6.28 \mathrm{~g})$, butanol $(50.33 \mathrm{~g})$, and hydromethanol (180.42 g) (Figure 1). The concentrations $(0,250$, $500,750$, and $1000 \mu \mathrm{L} / \mathrm{mL})$ of the hexane, dichloromethane, ethyl acetate, and butanol fractions were analyzed.

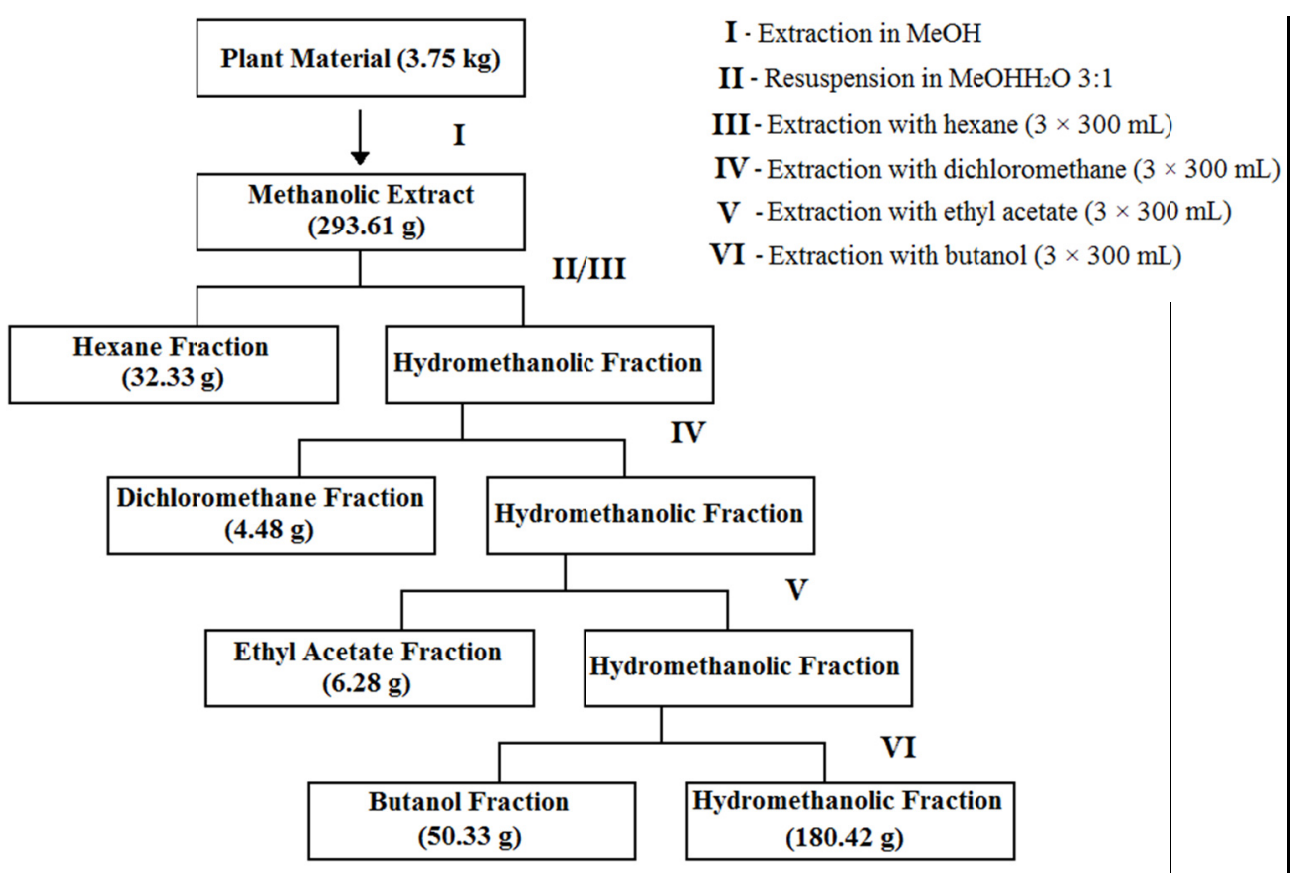

Figure 1. Fractionation of Sorghum bicolor (L.) Moench crude extract by by liquid-liquid extraction

\subsection{Biological Material}

Morning glory and slim amaranth seeds were purchased from Cosmos Agrícola Produção e Serviços Rurais Ltda, a company that specializes in the production of weed seeds. The registration number on SisGen is AED2337.

\subsection{Experimental Conduct}

Before the implantation and evaluation of each experiment, the stand, germination chamber, experimenter's hands, and materials were disinfected. The seeds were then selected for size and shape according to their phenotypic characteristics, and immersed in a $2 \%$ sodium hypochlorite solution $(\mathrm{NaClO})$ for 1-2 min. Finally, the seeds were washed extensively with distilled water.

\subsection{Evaluation of Germination}

The dichloromethane, hexane, butanol, and ethyl acetate fractions at different concentrations $(0,250,500,750$, and $1000 \mu \mathrm{L} / \mathrm{mL}$ ) were dissolved in $5 \mathrm{~mL}$ of $50 \% \mathrm{MeOH} / \mathrm{H}_{2} \mathrm{O}$ and distributed in a $29 \times 9 \times 2 \mathrm{~cm}$ Petri dish, on two sheets of paper for germination. For $24 \mathrm{~h}$, the fractions remained at rest for complete evaporation of methanol. In the control only, $5 \mathrm{~mL}$ of $50 \% \mathrm{MeOH} / \mathrm{H}_{2} \mathrm{O}$ were added to the Petri dish. Five replicates of each treatment were performed, where each replicate contained 25 morning glory or slim amaranth seeds distributed in Petri dishes.

After sowing, the Petri dishes were conditioned in a BOD germination chamber at $25{ }^{\circ} \mathrm{C}$, with a 12 -h photoperiod, for 7 and 14 days for the morning glory and slim amaranth, respectively.

For the evaluation of germination of the seeds, daily counts of the morning glory and slim amaranth were carried out for 7 and 14 days, respectively. From the sowing, germinated seeds that presented root protrusion at about 2 $\mathrm{mm}$ were assessed, as described by Hartmann, Kester, Davies, and Geneve (2001).

\subsubsection{Percentage of Germination (\% G)}

The percentage of germination (\% G) was obtained by representing the percentage of seeds germinated in relation to the total number of seeds per plate under the given experimental conditions, determined as follows:

$$
\% \mathrm{G}=\left(\mathrm{ni} \times \mathrm{N}^{-1}\right) \times 100
$$


where, $\Sigma \mathrm{ni}=$ total number of germinated seeds; $\mathrm{N}^{-1}=$ number of seeds arranged to germinate.

\subsubsection{Speed of Accumulated Germination}

The speed of accumulated germination (AS) was obtained using the equation proposed by Ferreira and Borghetti (2004):

$$
\mathrm{AS}=\mathrm{G} 1 / \mathrm{N} 1+\mathrm{G} 2 / \mathrm{N} 2+\ldots \mathrm{Gn} / \mathrm{Nn}
$$

where, $\mathrm{G}=$ number of seeds; $\mathrm{N}=$ number of days after sowing.

\subsection{Initial Growth Assessment}

The initial growth of invasive plants was verified from the length of the seedling, as well as the respective fresh and dry biomass weights.

\subsubsection{Seedling Length}

The length of the seedlings was determined by the end of the main root to its stem apex, measured using a millimeter ruler. Only seedlings with developmental capacity were measured (Ministério da Agricultura e Reforma Agrária [MAPA], 2009).

\subsubsection{Seedling Biomass}

Afterwards, the fresh biomass weights of the morning glory and slim amaranth seedlings were obtained by weighing on an analytical balance. Subsequently, the samples were properly conditioned in paper bags and placed in an oven for drying at $60{ }^{\circ} \mathrm{C}$ to obtain the dry biomass weight (Borella \& Pastorini, 2009).

\subsection{Statistical Analysis}

The experimental design was completely randomized with five replicates of each treatment. The data were evaluated by analysis of variance, and the means between treatments were compared by the Scott-Knott test at 5\% significance (Scott \& Knott, 1974). The data were transformed on a logarithmic scale. The software used was SISVAR of the Federal University of Lavras-UFLA (Ferreira, 2014).

\section{Results}

As shown in Table 1, the results indicated that the dichloromethane fraction of sorghum significantly inhibited in all variables analyzed, with the most significant effects being observed at the highest concentrations analyzed (750 and $1000 \mathrm{ppm}$ ) on morning glory seedlings (Ipomoea grandifolia [Dammer] O’Donell). The hexane fraction showed no significant difference in any of the analyses of the invasive plant.

Table 1. Effects of dichloromethane and hexane fractions of sorghum at different concentrations $(250,500,750$, and $1000 \mathrm{ppm}$ ) on the growth (length and fresh and dry biomass weights) and germination (\% G and AS) of Ipomoea grandifolia (Dammer) O'Donell. Control experiments are indicated as water + methanol (met)

\begin{tabular}{llllll}
\hline Treatment (ppm) & Length $(\mathbf{c m})$ & Fresh Biomass Weight $(\mathbf{g})$ & Dry Biomass Weight $(\mathbf{g})$ & Germination (\%) & AS \\
\hline H $_{\mathbf{2}}$ + MET & $6.3572 \pm 0.2624 \mathrm{Aa}$ & $0.702 \pm 0.0642 \mathrm{Aa}$ & $0.049 \pm 0.0016 \mathrm{Aa}$ & $82.40 \pm 1.4509 \mathrm{Ba}$ & $19.58 \pm 0.446 \mathrm{Aa}$ \\
DIC 250 & $3.9597 \pm 0.1816 \mathrm{~B}$ & $0.701 \pm 0.0650 \mathrm{~A}$ & $0.050 \pm 0.0020 \mathrm{~A}$ & $88.00 \pm 1.2649 \mathrm{~A}$ & $17.26 \pm 0.974 \mathrm{~A}$ \\
DIC 500 & $3.4775 \pm 0.3061 \mathrm{~B}$ & $0.580 \pm 0.0254 \mathrm{~A}$ & $0.042 \pm 0.0027 \mathrm{~A}$ & $86.40 \pm 3.2497 \mathrm{~A}$ & $15.19 \pm 0.703 \mathrm{~B}$ \\
DIC 750 & $2.7120 \pm 0.2152 \mathrm{C}$ & $0.337 \pm 0.0230 \mathrm{~B}$ & $0.030 \pm 0.0030 \mathrm{~B}$ & $76.80 \pm 1.9596 \mathrm{~B}$ & $11.02 \pm 0.977 \mathrm{~B}$ \\
DIC 1000 & $2.6764 \pm 0.2128 \mathrm{C}$ & $0.467 \pm 0.0320 \mathrm{~B}$ & $0.031 \pm 0.0030 \mathrm{~B}$ & $80.00 \pm 2.5299 \mathrm{~B}$ & $11.18 \pm 0.917 \mathrm{C}$ \\
HEX 250 & $5.5280 \pm 0.5135 \mathrm{a}$ & $0.758 \pm 0.0780 \mathrm{a}$ & $0.045 \pm 0.0040 \mathrm{a}$ & $88.80 \pm 1.4967 \mathrm{a}$ & $21.62 \pm 0.695 \mathrm{a}$ \\
HEX 500 & $6.6955 \pm 0.4629 \mathrm{a}$ & $0.816 \pm 0.0632 \mathrm{a}$ & $0.049 \pm 0.0030 \mathrm{a}$ & $83.20 \pm 1.4967 \mathrm{a}$ & $19.47 \pm 0.519 \mathrm{a}$ \\
HEX 750 & $6.6250 \pm 0.3120 \mathrm{a}$ & $0.866 \pm 0.0730 \mathrm{a}$ & $0.050 \pm 0.0040 \mathrm{a}$ & $83.20 \pm 4.9640 \mathrm{a}$ & $18.23 \pm 1.755 \mathrm{a}$ \\
hex 1000 & $6.2108 \pm 0.4122 \mathrm{a}$ & $0.786 \pm 0.0780 \mathrm{a}$ & $0.049 \pm 0.0030 \mathrm{a}$ & $85.60 \pm 4.1183 \mathrm{a}$ & $18.49 \pm 0.610 \mathrm{a}$ \\
\hline
\end{tabular}

Note. Upper- and lower-case letters represent the dichloromethane and hexane fractions, respectively. Statistically distinct results are represented by different letters according to the Scott-Knott test at 5\% significance. Data are represented as averages \pm standard error of the mean (SEM).

The negative allelopathic effect of the dichloromethane fraction on the length of the morning glory seedlings was verified at all analyzed length concentrations, and a reduction of up to $57.9 \%(1000 \mathrm{ppm})$ was observed when compared to that in the control experiment (water + methanol).

Regarding biomass weight, dry and fresh, both were reduced at concentrations of 750 and $1000 \mathrm{ppm}$ of the dichloromethane fraction. A concentration of $750 \mathrm{ppm}$ showed a greater reduction, decreasing the fresh biomass 
weight by $51.99 \%$ and dry biomass weight by $38.78 \%$.

Considering germination, the dichloromethane fraction of sorghum increased the percentage of germination (\% G) at concentrations of 250 and $500 \mathrm{ppm}$, with stimuli of $6.8 \%$ and $4.85 \%$, respectively. As for the speed of accumulated germination (AS), there was a reduction in concentrations higher or equal than $500 \mathrm{ppm}$, and an inhibition of $42.9 \%$ was observed at the highest concentration (1000 ppm).

Table 2 illustrates the ethyl acetate and butanol data on sorghum fractions, considering Ipomoea grandifolia (Dammer) O’Donell seedlings.

Table 2. Effects of ethyl acetate and butanol fractions of sorghum at different concentrations $(250,500,750$, and $1000 \mathrm{ppm})$ on the growth (length and fresh and dry biomass weight) and germination (\% G and AS) of Ipomoea grandifolia (Dammer) O'Donell. Control experiments are indicated as water + methanol (met)

\begin{tabular}{llllll}
\hline Treatment (ppm) & Length (cm) & Fresh Biomass Weight (g) & Dry Biomass Weight (g) & Germination (\%) & AS \\
\hline H $_{2}$ O + MET & $7.8511 \pm 0.4904 \mathrm{Aa}$ & $1.052 \pm 0.0693 \mathrm{Aa}$ & $0.046 \pm 0.0032 \mathrm{Ab}$ & $85.33 \pm 4.8075 \mathrm{Aa}$ & $21.42 \pm 0.939 \mathrm{Aa}$ \\
ACET 250 & $5.4116 \pm 0.2040 \mathrm{~A}$ & $1.086 \pm 0.0392 \mathrm{~A}$ & $0.060 \pm 0.0023 \mathrm{~A}$ & $88.80 \pm 0.8000 \mathrm{~A}$ & $20.12 \pm 0.361 \mathrm{~A}$ \\
ACET 500 & $5.0696 \pm 0.1445 \mathrm{~B}$ & $1.102 \pm 0.0449 \mathrm{~A}$ & $0.054 \pm 0.0004 \mathrm{~A}$ & $82.40 \pm 2.0397 \mathrm{~A}$ & $15.42 \pm 0.546 \mathrm{~B}$ \\
ACET 750 & $4.8255 \pm 0.1635 \mathrm{~B}$ & $1.107 \pm 0.0550 \mathrm{~A}$ & $0.059 \pm 0.0030 \mathrm{~A}$ & $83.20 \pm 1.4967 \mathrm{~A}$ & $15.43 \pm 0.135 \mathrm{~B}$ \\
ACET 1000 & $4.5095 \pm 0.1979 \mathrm{~B}$ & $0.851 \pm 0.0532 \mathrm{~B}$ & $0.052 \pm 0.0022 \mathrm{~A}$ & $76.80 \pm 3.6662 \mathrm{~A}$ & $14.56 \pm 0.364 \mathrm{~B}$ \\
BUT 250 & $6.9077 \pm 0.3366 \mathrm{~b}$ & $1.270 \pm 0.1082 \mathrm{a}$ & $0.057 \pm 0.0041 \mathrm{a}$ & $88.00 \pm 4.1954 \mathrm{a}$ & $22.44 \pm 0.649 \mathrm{a}$ \\
BUT 500 & $7.5924 \pm 0.0770 \mathrm{a}$ & $1.201 \pm 0.1100 \mathrm{a}$ & $0.056 \pm 0.0017 \mathrm{a}$ & $82.40 \pm 3.7096 \mathrm{a}$ & $19.73 \pm 0.433 \mathrm{a}$ \\
BUT 750 & $7.7337 \pm 0.0958 \mathrm{a}$ & $1.134 \pm 0.1122 \mathrm{a}$ & $0.063 \pm 0.0041 \mathrm{a}$ & $74.40 \pm 6.4002 \mathrm{a}$ & $17.84 \pm 1.739 \mathrm{~b}$ \\
BUT 1000 & $6.2307 \pm 0.2868 \mathrm{~b}$ & $0.948 \pm 0.0187 \mathrm{a}$ & $0.049 \pm 0.0027 \mathrm{~b}$ & $75.20 \pm 3.4410 \mathrm{a}$ & $16.50 \pm 0.382 \mathrm{~b}$ \\
\hline
\end{tabular}

Note. Upper- and lower-case letters represent the ethyl acetate and butanol fractions, respectively. Statistically distinct results were represented by different letters according to the Scott-Knott test at 5\% significance. Data are represented as averages \pm standard error of the mean (SEM).

It was found that the ethyl acetate fraction reduced seedling length at concentrations of 500, 750 and $1000 \mathrm{ppm}$, while the butanol fraction decreased seedling size at concentrations of 250 and $1000 \mathrm{ppm}$. The highest reductions were observed at $1000 \mathrm{ppm}$ in both fractions, decreasing by $42.56 \%$ and $20.64 \%$ in the ethyl acetate and butanol fractions, respectively.

The fresh biomass weight was inhibited (19.11\%) only in the ethyl acetate fraction of $1000 \mathrm{ppm}$. Regarding dry biomass weight, a positive influence was found in the butanol fraction, with a stimulus mostly at $750 \mathrm{ppm}$, increasing by $36.96 \%$ compared to that in the control.

In relation to germination, there were no statistical differences in the germination percentage. However, the speed of accumulated germination of Ipomoea grandifolia (Dammer) O'Donell was observed in both fractions, with the highest inhibitions at $1000 \mathrm{ppm}$, reduced by $32.03 \%$ and $22.97 \%$ in the ethyl acetate and butanol fractions, respectively.

Table 3 shows that the hexane fraction did not alter growth (length and fresh biomass weight) of slim amaranth seedlings. Data on dry biomass weight, as well as on the other fractions analyzed, were not presented because they were not detected on the balance owing to the reduced size of the species.

Table 3. Effect of the hexane fraction of sorghum at different concentrations (250 and $500 \mathrm{ppm})$ on growth (length and fresh biomass weight) and germination (\% G and AS) of Amaranthus hybridus L. Control experiments are indicated as water + methanol (met)

\begin{tabular}{lllll}
\hline Treatment (ppm) & Length (cm) & Fresh Biomass Weight (g) & Germination (\%) & AS \\
\hline H $_{2}$ O MET & $0.7486 \pm 0.0696 \mathrm{a}$ & $0.0246 \pm 0.0022 \mathrm{a}$ & $40.80 \pm 2.9395 \mathrm{a}$ & $4.197 \pm 0.238 \mathrm{a}$ \\
HEX 250 & $0.6992 \pm 0.0488 \mathrm{a}$ & $0.0481 \pm 0.0055 \mathrm{a}$ & $29.33 \pm 1.3334 \mathrm{~b}$ & $2.690 \pm 0.369 \mathrm{~b}$ \\
HEX 500 & $0.6292 \pm 0.0426 \mathrm{a}$ & $0.0199 \pm 0.0024 \mathrm{a}$ & $24.00 \pm 2.3095 \mathrm{~b}$ & $1.893 \pm 0.260 \mathrm{~b}$ \\
HEX 750 & - & - & - \\
HEX 1000 & - & - & - & - \\
\hline
\end{tabular}

Note. Different letters indicate statistically distinct results, according to the Scott-Knott test at 5\% significance. Data are represented as averages \pm standard error of the mean (SEM). 
The percentage and speed of accumulated germination were inhibited at concentrations of 250 and $500 \mathrm{ppm}$. The $500 \mathrm{ppm}$ concentration demonstrated greater effects, indicating reductions of $41.18 \%$ in the $\% \mathrm{G}$ and $54.9 \%$ in the AS.

Experiments were also performed using the dichloromethane and ethyl acetate fractions on Amaranthus hybridus L. However, these fractions drastically inhibited the initial germination and development of this plant, making it impossible to verify the parameters proposed in this work. Similar results were found with the highest concentrations (750 and $1000 \mathrm{ppm}$ ) of the hexane fraction.

The butanol fraction promoted a significant increase in the length of Amaranthus hybridus L. at a concentration of 1000 ppm, with an increase of $33.53 \%$ in relation to the control, as shown in Table 4 .

Table 4. Effect of the butanol fraction of sorghum at different concentrations $(250,500,750$, and $1000 \mathrm{ppm})$ on the growth (length and fresh biomass weight) and germination ( $\% \mathrm{G}$ and AS) of Amaranthus hybridus L. Control experiments are indicated as water + methanol (met)

\begin{tabular}{lllll}
\hline Treatment (ppm) & Length (cm) & Fresh Biomass Weight $(\mathbf{g})$ & Germination $(\%)$ & AS \\
\hline H $_{2}$ O + MET & $0.7777 \pm 0.0326 \mathrm{~b}$ & $0.0426 \pm 0.0006 \mathrm{a}$ & $58.40 \pm 3.4872 \mathrm{a}$ & $4.1364 \pm 0.182 \mathrm{a}$ \\
BUT 250 & $0.7685 \pm 0.0523 \mathrm{~b}$ & $0.0230 \pm 0.0017 \mathrm{~b}$ & $66.67 \pm 5.8120 \mathrm{a}$ & $4.1962 \pm 0.342 \mathrm{a}$ \\
BUT 500 & $0.8531 \pm 0.0463 \mathrm{~b}$ & $0.0270 \pm 0.0013 \mathrm{a}$ & $61.60 \pm 4.1184 \mathrm{a}$ & $4.2926 \pm 0.148 \mathrm{a}$ \\
BUT 750 & $0.8293 \pm 0.0669 \mathrm{~b}$ & $0.0369 \pm 0.0012 \mathrm{a}$ & $55.20 \pm 3.4410 \mathrm{a}$ & $4.4207 \pm 0.165 \mathrm{a}$ \\
BUT 1000 & $1.0385 \pm 0.0494 \mathrm{a}$ & $0.0345 \pm 0.0009 \mathrm{a}$ & $45.60 \pm 3.2497 \mathrm{a}$ & $2.9617 \pm 0.117 \mathrm{~b}$ \\
\hline
\end{tabular}

Note. Different letters indicate statistically distinct results, according to the Scott-Knott test at 5\% significance. Data are represented as averages \pm standard error of the mean (SEM).

In contrast, the fresh biomass weight was inhibited at $250 \mathrm{ppm}$, reduced by $46.01 \%$ compared to that of the control. However, no differences were observed in the percentage of germination of Amaranthus hybridus L. when the seeds were exposed to the butanol fraction. The speed of accumulated germination was inhibited only at a concentration of $1000 \mathrm{ppm}$, with a reduction of $28.4 \%$ compared to that of the control.

\section{Discussion}

Allelopathic substances are capable of inhibiting germination and growth, as they interfere with cell division, membrane permeability, enzyme activation, and hormone production in plants (Rodrigues, Rodrigues, \& Reis, 1992). Allelopathic compounds may be a form of communication because they allow plants to distinguish between organisms that are harmful or beneficial (Almeida, Lucchesi, \& Abbado, 1997).

Germination is a sequence of physiological events that can be influenced by factors external and internal to the seeds, in which each factor can act independently or interact with others to optimize the percentage, uniformity, and speed of germination. The germination speed is affected mainly by controllable and manipulable external (environmental) factors and may undergo changes because of compounds present in the substrate (Nassif, Vieira, \& Fernandes, 1998).

Ferreira and Áquila (2000) stated that changes in the germination pattern may be due to effects on enzyme and receptor conformations, membrane permeability, DNA transcription and translation, respiration, oxygen sequestration, secondary messenger function, or a combination of the mentioned factors.

Research conducted in the field by Trezzi and Vidal (2004) showed that sorghum straw, when increased in terms of its soil cover, reduced infestations of Brachiaria. plantaginea and Sida. rhombifolia weeds. Ferreira, Medeiros, and Soares (2008), using allelopathic compounds, verified the inhibition of AS of Eragrostis plana Nees over Bahia grass and kazungula grass, which was in accordance with the findings of Gomes et al. (2018), in which the AS of lettuce was affected by extracts with sorgoleone.

Many studies related to allelopathy have only evaluated the effects exerted by allelochemicals on the germination and growth of the test plant and have not investigated the cellular events related to physiological changes in the plant system or plant growth (Pires et al., 2001).

Sorghum is an important cereal that can assist in the control of invasive plants. This is possibly owing to its ability to produce substances located in the trichomes of its roots, including sorgoleone, capable of persisting in the soil for extended periods. Sorgoleone is a proven allelopathic compound and is capable of inhibiting the 
development of certain plants by primarily inhibiting the photosynthetic pathway (I. L. V. L. Santos, Silva, S. L. Santos, \& Maia, 2012).

The alternative control of weeds through the phytotoxics properties of sorghum could be a useful tool to enable the productive systems of conservation, taking advantage of the use of agrochemicals (Karam, Silva, Vasconcelos, Rodrigues, Mourão, 2011). Sorghum plants release both hydrophobic and hydrophilic chemicals into the environment. The action of these substances on the growth and development of weeds depends, especially, on the genotype used, part of the plant considered, and environmental conditions (Trezzi, Vidal, \& Kruse, 2005).

T. M. L. Barbosa, Ferreira, Souza, L. C. A. Barbosa, and Casali (1998) also observed a phytotoxic effect of allelochemicals from the root exudates of sorghum seedlings, in which growth was inhibited and the dry matter and leaf area of lettuce were decreased. Other authors, such as Navas, Monteiro, Medeiros, and Pereira (2018) and Pires, Prates, Filho, Oliveira, and Faria (2001), have found some inhibitory effects of allelopathic compounds on weed length.

The results of this research indicate that the dichloromethane and ethyl acetate fraction extracts of sorghum are phytotoxics allelochemicals, which promote a high bioherbicidal effect. Similar findings occurred at high concentrations of the hexane fraction, presenting a phytotoxic effect on Amaranthus hybridus L. Poor development and certain characteristics of the radicle can be considered as factors that indicate plant susceptibility to phytotoxics effects (Souza-Filho \& Duarte, 2007). However, it is necessary to identify these secondary metabolites extracted in each fraction and investigate parameters, such as the osmotic potential, enzymatic activities, lipid peroxidation, and cell viability, to elucidate the mechanism of action.

Identifying phytotoxics allelochemicals can lead to the discovery of natural substances with inhibitory characteristics, since some herbicides can cause cell death and induce oxidative stress (Silva et al., 2016). It is worth mentioning that a large part of laboratory findings on allelopathy possibly remain unconfirmed under natural conditions, since the simultaneous occurrence of biotic and abiotic factors may interfere with the final results (Tur, Borella, \& Pastorini, 2010).

\section{Conclusion}

It was concluded that the dichloromethane and ethyl acetate fractions had a phytotoxic effect on the morning glory and slim amaranth varieties, which indicated that isolated compounds in these fractions could inhibit the initial growth of these invasive plants, thereby acting as bioherbicides.

The butanol fraction had no inhibitory effects on the species studied. The hexane fraction did not show significant effects on morning glory; however, it had extensive phytotoxics effects on slim amaranth.

\section{References}

Almeida, A. R. P., Lucchesi, A. A., \& Abbado, M. R. (1997). Efeito alelopático de espécies de brachiárias Griseb. sobre algumas leguminosas forrageiras tropicais. II. Avaliações em casa de vegetação. Boletim de Indústria Animal, 54, 45-54.

Almeida, F. S. (1991). Efeitos alelopáticos de resíduos vegetais. Pesquisa Agropecuária Brasileira, 26(2), 221-223.

Barbosa, T. M. L., Ferreira, F. A., Souza, I. F., Barbosa, L. C. A., \& Casali, V. W. D. (1998). Caracterização química e efeitos alelopáticos de exsudatos radiculares de plântulas de sorgo sobre alface. Planta Daninha, 16(2) 153-162. https://doi.org/10.1590/S0100-83581998000200009

Borella, J., \& Pastorini, L. H. (2009). Influência alelopática de Phytolacca dioica L. na germinação e crescimento inicial de tomate e picão-preto. Biotemas, 22(3), 67-75. https://doi.org/10.5007/2175-7925.2009v22n3p67

Brass, F. E. B. (2009). Análise de atividade alelopática de extrato aquoso de falsa-murta sobre a germinação de picão preto e caruru. Enciclopédia Biosfera, 5(8), 1-19.

Carvalho, W. P., Teixeira, L. G. V., Neto, D. O. A., Moreira, J. M. S., \& Cunha, C. E. (2016). Alelopatia de resíduos de plantas de cobertura no controle de braquiária cv. Marandu. R. Bras. Bioci., 14(2), 60-69.

Ferreira, A. G., \& Aquila, M. E. A. (2000). Alelopatia: Uma área emergente da ecofisiologia. R. Bras. Fisiol.Veg., 12, 175-204.

Ferreira, A. G., \& Borghetti, F. (2004). Germinação: do básico ao aplicado. Porto Alegre, RS: Artmed.

Ferreira, D. F. (2014). Sisvar: Um guia dos seus procedimentos de comparações múltiplas Bootstrap. Ciênc. Agrotec., 38(2), 109-112. https://doi.org/10.1590/S1413-70542014000200001 
Ferreira, N. R., Medeiros R. B., \& Soares, G. L. G. (2008). Potencial alelopático do capim-annoni-2 (Eragrostis plana Nees) na germinação de sementes de gramíneas perenes estivais. Revista Brasileira de Sementes, 30(2), 043-050. https://doi.org/10.1590/S0101-31222008000200006

Gazziero, D. L. P., Brighenti, A. M., Lollato, R. P., Pitelli, R. A., Voll, E., Oliveira, E., \& Moriyama, R. T. (2006). Manual de identificação de plantas daninhas da cultura da soja (p. 115). Londrina: Embrapa Soja.

Gomes, D. S., Bevilaqua, N. C., Silva, F. B., \& Monquero, P. A. (2014). Supressão de plantas espontâneas pelo uso de cobertura vegetal de crotalária e sorgo. Rev. Bras. De Agroecologia, 9(2), 206-213.

Gomes, T. C., Karam, D., Marinho, C. G. S., Martins, B. A. B., Simone, M. L. F., \& Okumura, F. (2018). Ação de extratos de sorgo na germinação de sementes de milho, alface e corda-de-viola (Ipomoea sp.). Revista Brasileira de Milho e Sorgo, 17(1), 168-176. https://doi.org/10.18512/1980-6477/rbms.v17n1p168-176

Hartmann, T. H., Kester, D. E., Davies, J. R. F. T., \& Geneve, R. (2001). Plant propagation: Principles and practices (7th ed.). Upper Saddle River, NJ: Prentice Hall.

IBGE (Instituto Brasileiro de Geografia e Estatística). (2016). População. Retrieved May 1, 2016, from http://www.ibge.gov.br/apps/populacao/projecao

Karam, D., Silva, J. A. A., Vasconcelos, G. M. P. V., Rodrigues, J. S., \& Mourão, S. A. (2011). Potencial de controle de plantas daninhas com massa verde de sorgo incorporada e em cobertura. X Congresso de Ecologia do Brasil, 16 a 22 de Setembro de 2011.

Landau, E. C., \& Sans, L. M. A. (2008). Cultivo do sorgo. Retrieved April 9, 2016, from http://www.cnpms. embrapa.br/publicacoes/sorgo_4_ed/clima.html

Lorenzi, H. (2000). Plantas daninhas do Brasil: Terrestres, aquáticas, parasitas e tóxicas (3rd ed.).

Magiero, E. C., Assmann, J. M., Marchese, J. A., Capelin, D., Paladini, M.V., \& Trezzi, M.M. (2009). Efeito alelopático de Artemisia annua L. na germinação e desenvolvimento inicial de plântulas de alface (Lactuca sativa L.) e leiteiro (Euphorbia heterophylla L.). Rev. Bras. Plantas Med., 11(3) 317-324. https://doi.org/ 10.1590/S1516-05722009000300014

MAPA (Ministério da Agricultura e Reforma Agrária). (2009). Regras para análise de sementes. Brasília, DF.

Marques, D. S., Fortes, A. M. T., Rosa, D. M., Dill, M. A., Mauli, M. M., Araldi, P., ... Refosco, R. M. C. (2005). Efeito alelopático de sabugueiro (Sambucus australis Cham. \& Schlecht) sobre o desenvolvimento de corda de viola (Ipomoea grandifolia Dammer) (pp. 50-52). XV Semana de Biologia, 26 à 30 de Setembro de 2005. http://www.unioeste.br/prg/download/anais_2005.pdf

Nassif, S. M. L., Vieira, I. G., \& Fernandes, G. D. (1998, April). Fatores externos (ambientais) que influenciam na germinação de sementes. Retrieved August 30, 2017, from http://www.ipef.br/tecsementes/ germinacao.asp

Navas, R., Monteiro, R., Medeiros, L. S., \& Pereira, M. R. R. (2018). Efeito alelopático de Chloroleucon tortum sobre Lactuca sativa e Bidens pilosa. Anais do VI CLAA, X CBA e V SEMDF, 13. Retrieved from http://cadernos.aba-agroecologia.org.br/index.php/cadernos/article/view/1387

Oliveira, J. S., Peixoto, C. P., Poelking, V. G. C., \& Almeida, A.T. (2015). Avaliação de extratos das espécies Helianthus annuus, Brachiaria brizantha e Sorghum bicolor com potencial alelopático para uso como herbicida natural. Rev. Bras. Plantas Med., 17(3), 379-384. https://doi.org/10.1590/1983-084X/13_040

Pinto, G. M. F. (2015). Os pesticidas, seus riscos e movimento no meio ambiente. Revista Eletrônica FACP, 3(8), $1-12$.

Pires, N. M., Prates, H. T., Filho, I. A. P, Oliveira, R. S. Jr., \& Faria, T. C. L. (2001). Atividade alelopática da leucena sobre espécies de plantas daninhas. Scientia Agricola, 58(1), 61-65. https://doi.org/10.1590/ S0103-90162001000100011

Pires, N. M., Souza, I. R. P., Prates, H. T., Faria, T. C. L., Filho, I. A. P., \& Magalhães, P. C. (2001). Efeito do extrato aquoso de leucena sobre o desenvolvimento, índice mitótico e atividade da peroxidase em plântulas de milho. R. Bras. Fisiol. Veg., 13(1), 55-65. https://doi.org/10.1590/S0103-31312001000100007

Ribas, P. P., \& Matsumura, A. T. S. (2009). A química dos agrotóxicos: Impacto sobre a saúde e meio ambiente. Revista Liberato, 10(14), 149-158. https://doi.org/10.31514/rliberato.2009v10n14.p149

Rodrigues, L. R. A., Rodrigues, T. J. D., \& Reis, R. A. (1992). Alelopatia em plantas forrageiras. Jaboticabal, SP: Funep. 
Rosado, L. D. S., Rodrigues, H. C. A., Pinto, J. E. B. P., Custódio, T. N., Pinto, L. B. B., \& Bertolucci, S. K. V. (2009). Alelopatia do extrato aquoso e do óleo essencial de folhas do manjericão "Maria Bonita" na germinação de alface, tomate e melissa. Revista Brasileira de Plantas Medicinais, 11(4), 422-428. https://doi.org/10.1590/S1516-05722009000400010

Santos, I. L. V. L., Silva, C. R. C., Santos, S. L., \& Maia, M. M. D. (2012). Sorgoleone: benzoquinona lipídica de sorgo com efeitos alelopáticos na agricultura como herbicida. Arq. Instituto Biologia, 79(1), $135-144$. https://doi.org/10.1590/S1808-16572012000100020

Scott, A., \& Knott, M. (1974). Cluster-Analysis method for grouping means in analysis of variance. Biometrics, 30(3), 507-512. https://doi.org/10.2307/2529204

Silva, C. B., Oliveira, M., Dias, J. F., Zanin, S. M. W., Santos, G. O., Cândido, A. C. S., ... Miguel, M. D. (2016). Atividade alelopática dos lixiviados de Asemeia extraaxillaris (Polygalaceae) sobre o crescimento de Ipomoea cordifolia. Rev. Bras. Pl. Med., 18(1), 215-222. https://doi.org/10.1590/1983-084X/14_093

Souza-Filho, A. P. S., \& Duarte, M. L. R. (2007). Atividade alelopática do filtrado de cultura produzido por Fusarium solani. Planta Daninha, 25(1), 227-230. https://doi.org/10.1590/S0100-83582007000100026

Teixeira, C. M., Araújo, J. B. S., \& Carvalho, G. J. (2004). Potencial alelopático de plantas de cobertura no controle de picão-preto (Bidens pilosa L.). Ciência e Agrotecnologia, 28(3), 691-695. https://doi.org/ 10.1590/S1413-70542004000300028

Trezzi, M. M., \& Vidal, R.A. (2004). Potencial de utilização de cobertura vegetal de sorgo e milheto na supressão de plantas daninhas em condição de campo: II-Efeitos da cobertura morta. Planta Daninha, 22(1), 1-10. https://doi.org/10.1590/S0100-83582004000100001

Trezzi, M. M., Vidal, R. A., \& Kruse, N. D. (2005). Fitotoxicidade de extratos hidrofóbicos e hidrofílicos de sorgo e milheto. Revista de Ciências Agroveterinárias, 4(1), 25-34.

Tur, C. M., Borella, J., \& Pastorini, L. H. (2010). Alelopatia de extratos aquosos de Duranta repens sobre a germinação e o crescimento inicial de Lactuca sativa e Lycopersicum esculentum. Revista Biotemas, 23(2), 13. https://doi.org/10.5007/2175-7925.2010v23n2p13

Zimdahl, R. L. (2007). Fundamentals of Weed Science (3rd ed.). San Diego, CA: Academic Press.

\section{Copyrights}

Copyright for this article is retained by the author(s), with first publication rights granted to the journal.

This is an open-access article distributed under the terms and conditions of the Creative Commons Attribution license (http://creativecommons.org/licenses/by/4.0/). 